\title{
Recent Developments in Kansas Residential Landlord-Tenant and Eviction Law
}

\author{
Suzanne Carey McAllister
}

\section{INTRODUCTION}

Even though the relationship between a residential landlord and tenant is a delicate one, oftentimes these arrangements go off without a hitch. Occasionally, however, disputes between a landlord and a tenant do arise, creating the need for courts to intervene. For example, when there is a breakdown in the landlord-tenant relationship, or when the tenant remains in the rental property after the lease has been terminated, the landlord usually invokes the Eviction statute ${ }^{1}$ to begin the legal process of properly removing a tenant who is no longer welcome.

This Article provides an up-to-date summary of recent developments in Kansas residential landlord-tenant law, including eviction law. More than thirty years ago, in 1975, the Kansas legislature codified the Kansas Residential Landlord and Tenant Act (KRLTA), which, along with the Eviction statute, regulates much of the landlord-tenant relationship. ${ }^{2}$ In general, Kansas landlord-tenant and eviction law has not changed in the last ten years. ${ }^{3}$ There has been fairly recent litigation, however, concerning the landlord's proper return of the tenant's security deposit

- Clinical Associate Professor, University of Kansas School of Law.

1. KAN. STAT. ANN. $\S \S 61-3801$ to $61-3808$ (2005).

2. KAN. STAT. ANN. $\S \S 58-2540$ to -2573 (2005). The Eviction statute was formerly called the Forcible Entry and Detainer statute and was found at KAN. STAT. ANN. \$\$ 61-2301 to -2311. Kansas courts have long regarded the residential lease as a contract subject to the parameters laid out in the KRLTA.

See also the Kansas Mobile Home Parks Residential Landlord and Tenant Act of 1992, which parallels the KRLTA in many areas. KAN. STAT. ANN. $\S \S 58-25,100$ to $-25,127$ (2005). The 1992 Act applies when the tenant owns the mobile home but leases the land upon which the home sits from the landlord. When both the mobile home and space are rented from the same landlord, the KRLTA applies.

3. See generally Stephen Kirschbaum, Prosecuting and Defending Forcible Entry and Detainer Actions, J. KAN. B. Ass'N, Sept. 1996, at 20 (providing an excellent and comprehensive overview of the KRLTA and the Forcible Entry and Detainer (FED) Statute, which is now called the Eviction statute); see also generally Lawrence R. McDonough, Wait a Minute! Residential Eviction Defense Is Much More Than "Did You Pay the Rent?", 28 WM. MrTCHELl L. ReV. 65 (2001) (discussing the legal issues regarding eviction). 
after a tenancy has ended and the enforceability of liquidated damages clauses. $^{4}$ The Kansas Court of Appeals has also considered whether a tenant can be charged fees for late rent and the circumstances under which a tenant may be assessed statutory damages for holding over. ${ }^{5}$ In addition to a few interpretive cases, there have been some statutory changes, including the addition of section 58-2570(e) to the KRLTA, which deals with documents or notices the landlord provides to the tenant regarding the tenant's intent to vacate a rental property, ${ }^{6}$ and the revamping of the Eviction statute, located at sections 61-3801 though 613808 of the Kansas Statutes. ${ }^{7}$ As well, this Article discusses how the impact of federal law on the practice of evictions, most notably the Fair Debt Collections Practices Act and the recently amended Bankruptcy Code, has brought to light the importance of understanding the effects of federal law on state practice. ${ }^{8}$

\section{RECENT NOTEWORTHY KANSAS RESIDENTIAL LANDLORD-TENANT CASES}

\section{A. Landlord's Retention of Security Deposits: General Principles and the Requirement of Actual Damages}

In Kansas, one of the most litigated issues in the residential landlordtenant context involves return of the tenant's security deposit at the end of the tenancy. ${ }^{9}$ A security deposit is defined as

\footnotetext{
4. See infra Part II.A.-C.

5. See infra Part II.D.

6. See infra Part III.A.

7. See infra Part III.C.

8. See infra Part IV.

9. See Geiger v. Wallace, 664 P.2d 846, 850 (Kan. 1983) (discussing damages awarded against a landlord for not itemizing deductions from a security deposit); Clark v. Walker, 590 P.2d 1043, 1045 (Kan. 1979) (discussing the "constitutionality of provisions of the Residential Landlord and Tenant Act"); A \& S Rental Solutions, Inc. v. Kopet, 76 P.3d 1057, 1058 (Kan. Ct. App. 2003) (determining whether a civil penalty can be levied under the statute governing the retum of security deposits); Heckard v. Martin, 958 P.2d 665, 668 (Kan. Ct. App. 1998) (stating that a landlord has thirty days to inspect the premises for damages deductible from the security deposit); Burgess $\mathrm{v}$. Stroud, 840 P.2d 1206, 1207 (Kan. Ct. App. 1992) (deciding whether a notice to vacate without a late payment notification can result in the forfeiture of a security deposit); Love v. Monarch Apartments, 771 P.2d 79, 82-83 (Kan. Ct. App. 1989) (awarding damages for the wrongful withholding of a security deposit); Vogel v. Haynes, 730 P.2d 1096, 1098 (Kan. Ct. App. 1986) (stating that failure to give notice of damages precludes the landlord from retaining the security deposit); Asbury v. Mauk, 687 P.2d 31, 34 (Kan. Ct. App. 1984) (discussing whether a security deposit could be considered in garnishment proceedings).
} 
any sum of money specified in a rental agreement . . . to be deposited with a landlord by a tenant as a condition precedent to the occupancy of a dwelling unit, which sum of money, or any part thereof, may be forfeited by the tenant under the terms of the rental agreement upon the occurrence or breach of conditions specified therein. ${ }^{10}$

Under section 58-2550(a) of the KRLTA, a landlord may collect a security deposit from the tenant prior to the tenant's move in. "I The amount of the security deposit allowed by statute is no more than one month's rent if the dwelling is unfurnished and no more than one and one-half month's rent if the dwelling is furnished. ${ }^{12}$ If the rental agreement allows the tenant to keep a pet, the landlord may charge an additional security deposit of no more than half of one month's rent. ${ }^{13}$

In general, after the tenant has moved out, the landlord may apply the security deposit to accrued rent and to any actual damages the tenant has made to the rental property. ${ }^{14}$ A landlord may also retain the tenant's security deposit if the tenant does not pay rent but instead applies any or all of the security deposit toward the rent. ${ }^{15}$ In this instance, if the rental agreement specifically provides for the forfeiture, a tenant who owes back rent forfeits his security deposit, and the landlord is then entitled to recover the rent due as if the deposit was never applied as such. ${ }^{16}$

As a practical matter, the landlord should conduct an inspection immediately after the tenant vacates the rental property because a balance, along with written itemization of costs and expenses assessed against the security deposit, is due to the tenant within thirty days after the tenant vacates. ${ }^{17}$ If the landlord fails to return the full or partial balance of the security deposit (with itemization of proper deductions taken from the deposit) within the thirty-day period, a civil penalty of

10. KAN. STAT. ANN. § 58-2543(m) (2005).

11. KAN. STAT, ANN. § 58-2550(a) (2005).

12. Id.

13. $I d$.

14. Id. $\S 58-2550(\mathrm{~b})$. Other states follow this same practice. See, e.g., FLA. STAT. ANN. $\S$ 83.49(1)(a)-(b), (3)(a) (2004) (requiring a landlord to return a tenant's security deposit, with interest earned, within fifteen days after the tenant vacates the rental property if the landlord does not have a claim against the security deposit); N.M. STAT. ANN. $\$ 47-8-18$ (c) (2003) (requiring the landlord to provide the tenant with an itemized list of deductions to be levied against the security deposit within thirty days of termination of the rental agreement).

15. KAN. STAT. ANN. §58-2550(d).

16. Id.; see also Clark v. Walker 590 P.2d 1043, 1050 (1979) (holding the rental agreement must explicitly include the forfeiture provision in the lease; otherwise, the landlord is precluded from retaining the tenant's security deposit as permitted under section 58-2550(d)).

17. See KAN. STAT. ANN. $\S 58-2550$ (b) (requiring a return of the deposit or an accounting of any expenses within thirty days). 
one and one-half times the amount wrongfully withheld will be assessed against the landlord. ${ }^{18}$ A tenant who has vacated the leased premises may file a suit against the landlord to recover the security deposit after the tenancy has ended if the tenant believes that the landlord failed to properly return some or all of the deposit. Because the amount in controversy typically does not exceed $\$ 4000$, actions to recover the security deposit are usually filed in small claims court. ${ }^{19}$

Since the KRLTA was enacted in 1975, there have been a number of cases in which the Kansas appellate courts have addressed the various rights and obligations of both landlords and tenants concerning the security deposit. ${ }^{20}$ In Wurtz $v$. Cedar Ridge Apartments, a case decided in 2001, the Kansas Court of Appeals addressed whether the landlord was entitled to enforce the language included within the security deposit provision, which allowed the landlord to retain the tenant's security deposit if she prematurely terminated her lease. ${ }^{21}$ The landlord and tenant in Wurtz entered into a year-long lease, from March 1, 1999 to February 29, 2000, with the tenant paying rent of $\$ 395$ per month. ${ }^{22}$ The tenant, Sarah R. Wurtz, paid a security deposit of $\$ 200$ prior to moving in. ${ }^{23}$ The security deposit provision in the rental agreement provided for a deposit "as security for the payment of all charges which may accrue and for the full and faithful performance of all the covenants and conditions of this Lease Agreement." ${ }^{24}$ It further provided that Cedar Ridge could retain the security deposit for accrued rent and damages as a result of Wurtz's premature termination of the rental agreement. ${ }^{25}$ Independent of and in addition to the security deposit clause, the lease contained a cancellation fee and forfeiture provision that required Wurtz, "upon early termination of the lease, to give 30 days' written notice, forfeit the security deposit, and pay a cancellation fee of $\$ 474 ., 26$

On October 1, 1999, Wurtz sought in writing to cancel the lease prematurely, claiming that the living conditions in the apartment were

18. See id. $\S 58-2550$ (c) (describing penalty imposed on a landlord for noncompliance with subsection (b)); see also Love v. Monarch Apartments, 771 P.2d 79, 82-83 (Kan. Ct. App. 1989) (holding the assessment of the civil penalty upon the landlord is mandatory if the landlord wrongfully withholds part or all of the tenant's security deposit).

19. See KAN. STAT. ANN. § 61-2703(a) (2005) (defining "small claim").

20. See supra note 9 (listing cases discussing the proper return of the tenant's security deposit at the end of tenancy).

21. Wurtz v. Cedar Ridge Apartments, 18 P.3d 299, 301-02 (Kan. Ct. App. 2001).

22. Id. at 301 .

23. Id.

24. Id. at 302 .

25. Id. at 301 .

26. Id. 
unacceptable. ${ }^{27}$ Wurtz's letter also requested return of the $\$ 200$ security deposit and waiver of the $\$ 474$ cancellation fee. ${ }^{28}$ Cedar Ridge immediately provided a written response to Wurtz on October 4, 1999, invoking the language of the lease. ${ }^{29}$ Specifically, Cedar Ridge countered that, per the lease, Wurtz must provide a written thirty-day notice to terminate the lease, forfeit the security deposit, and pay the $\$ 474$ cancellation fee. ${ }^{30}$ On October 29,1999 , Wurtz completed a notice to move form asserting that she had bought a house. ${ }^{31}$ She moved out of the apartment and paid prorated rent in the amount of $\$ 356$ for the month of November. ${ }^{32}$ Thereafter, Cedar Ridge conducted an inspection on November 9, 1999, and assessed the following costs to Wurtz on its inspection sheet: a $\$ 474$ cancellation fee and $\$ 104$ in cleaning and miscellaneous expenses. ${ }^{33}$ Cedar Ridge also indicated that Wurtz forfeited the security deposit of $\$ 200$ because she prematurely terminated the lease. ${ }^{34}$ They deducted $\$ 106$ for overpayment of November rent, ${ }^{35}$ calculating a total of $\$ 472$ owed by Wurtz. ${ }^{36}$

Wurtz refused to pay Cedar Ridge the $\$ 472$ it claimed she owed. ${ }^{37}$ After failed attempts at negotiating with Cedar Ridge, Wurtz filed a small claims action requesting that the court order the return of her security deposit and make a finding that the $\$ 474$ cancellation fee was grossly unfair. ${ }^{38}$ Cedar Ridge filed a counterclaim seeking the $\$ 472$ they originally demanded from Wurtz. ${ }^{39}$ The small claims court denied both parties' claims. $^{40}$

On Wurtz's de novo appeal to the district court, the judge determined that the language in the clause allowing Cedar Ridge to retain the security deposit due to Wurtz's failure to perform her obligations under the lease was a liquidated damages clause and therefore precluded under section 58-2550(b) of the KRLTA. ${ }^{41}$ The district court awarded Cedar

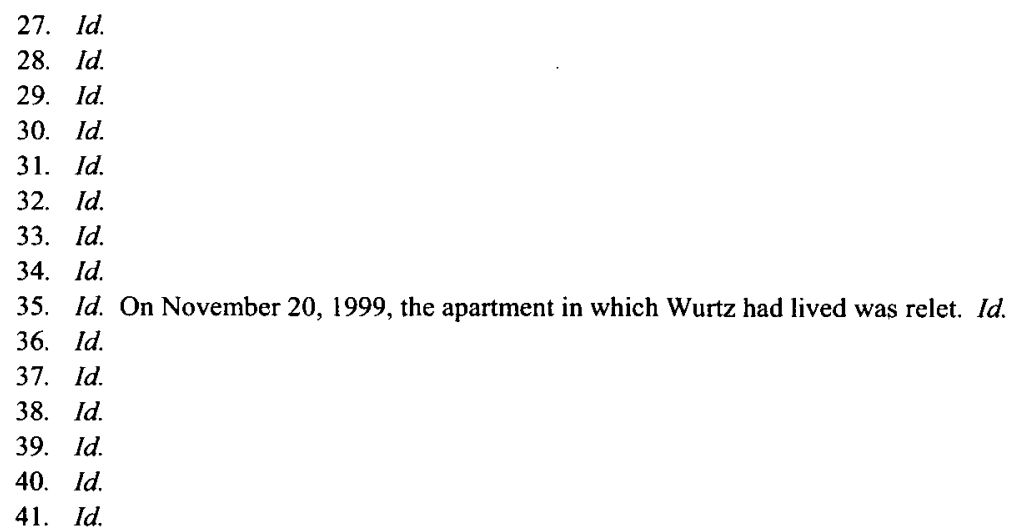


Ridge the cost to clean the apartment- $\$ 104$ assessed as actual damages-and gave Wurtz credit for the overpayment of November rent $(\$ 106){ }^{42}$ Thus, the district court determined that Cedar Ridge wrongfully withheld $\$ 202$. The court then assessed a civil penalty of one and one-half the amount wrongfully withheld (\$202) to determine that Wurtz was entitled to $\$ 303$, plus the $\$ 202$ wrongfully withheld, for a total of $\$ 505 .^{43}$

Probably equally significant in Wurtz was the district court's refusal to consider whether the small claims court correctly denied Cedar Ridge's request for enforcement of the cancellation fee, which would have allowed Cedar Ridge to recover $\$ 474$ from Wurtz. The district court ruled that Cedar Ridge had failed to preserve the issue for appeal. ${ }^{44}$

Cedar Ridge, dissatisfied with the district court's ruling, appealed the judgment to the Kansas Court of Appeals, wherein, once again, one of the issues addressed was the enforceability of the security deposit provision that entitled Cedar Ridge to retain Wurtz's security deposit due to her failure to fulfill the terms of the lease. ${ }^{45}$ The Wurtz court referenced a 1986 Kansas case, Vogel v. Haynes, in which the Court of Appeals in that instance reviewed a particular security deposit provision in a residential lease to determine whether the language included liquidated damages. ${ }^{46}$ The security deposit clause in Vogel was similar to the one contained in Wurtz's lease. It provided that a "deposit [is required] . . . as security to the Lessor for the performance of this Agreement." The clause further stated:

The deposit shall be returned if in the Lessor's (Owner's) opinion all of the Lessee's (Renter's) obligations in this Agreement have been fulfilled on the termination of this Agreement and the Lessee (Renter) has remained for a minimum of one (1) year from the date that Lessee (Renter) paid the first full month rent under this Agreement.

The rental agreement between the tenant, Rhoda Vogel, and the landlord, William G. Haynes, was structured as a month-to-month tenancy allowing either the landlord or tenant to terminate the tenancy by providing written thirty-day notice. ${ }^{48}$ Vogel resided in the apartment for

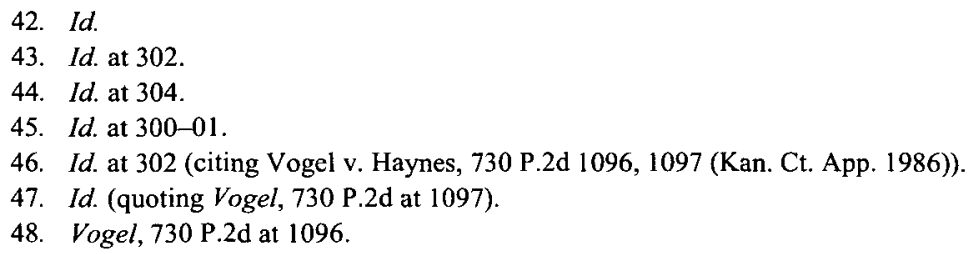


approximately six months before terminating the tenancy in writing. ${ }^{49}$ Consequently, she did not comply with the security deposit provision, which required her to live in the leased premises for at least one year, and ostensibly forfeited the security deposit she paid to the landlord. ${ }^{50}$ In Vogel, the court determined that the provision requiring return of the security deposit if Vogel failed to live in the rental property for a year was a liquidated damages provision that could not be included in the security deposit clause. ${ }^{51}$ The court further reasoned that the landlord was precluded from assessing a lump sum penalty against Vogel because "K.S.A. 58-2550(b) provides that the landlord may only deduct for actual damages sustained" and nothing more. ${ }^{52}$

Using Vogel as guidance, the Wurtz court reasoned that, under section 58-2550(b), the security deposit covers actual damages, and the landlord must itemize such damages in the form of a written notice to the tenant. ${ }^{53}$ Furthermore, the court stressed, liquidated damages are by their very nature not itemized. ${ }^{54}$ Thus, the court determined, the statute must be interpreted to permit only actual, but not liquidated, damages. ${ }^{55}$ Relying on Vogel's interpretation of section 58-2550(b), the Wurtz court held "the district court correctly refused to award Cedar Ridge the entire security deposit as liquidated damages, but correctly deducted the $\$ 104$ in [actual] damages from the deposit." 56

As to the civil penalty assessed against Cedar Ridge, the appeals court found that the district court erred in its calculation, noting that the rent overpayment amount of $\$ 106$ should not have been considered in its calculation. ${ }^{57}$ Rather, the court noted, the civil penalty should have been calculated in the following manner: $\$ 200$ (security deposit) minus $\$ 104$ (actual damages), for a total of $\$ 96$, as this is the amount Cedar Ridge wrongfully withheld. Thus, $\$ 96$ (the amount wrongfully withheld) multiplied by the civil penalty of one and one-half equals $\$ 144$, totaling $\$ 240$ owed to Wurtz. ${ }^{58}$

In summary, Kansas case law interpreting section 58-2550(b) establishes that, when withholding all or part of a tenant's security

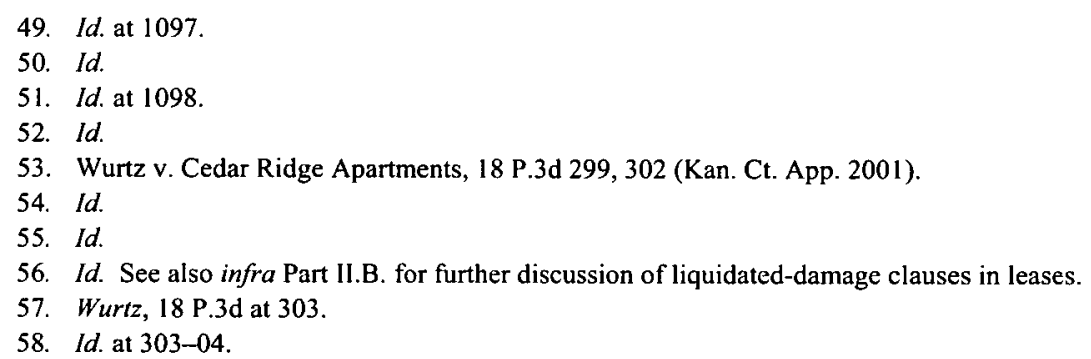


deposit, a landlord shall be entitled to retain only actual damages suffered, such as accrued rent and damages to the leased premises. A landlord is required to provide the tenant with written itemization of all damages deducted from the security deposit. If the landlord withholds any or all of a tenant's security deposit for any reason other than what the statute allows, the landlord shall be assessed the civil penalty provided in section 58-2550(c).

\section{B. Cancellation Fee Provisions: The Questionable Legality in Residential Leases}

Probably the most curious issue in Wurtz, which the Kansas Court of Appeals did not address, was the legality of the cancellation fee that was included in the parties' rental agreement. ${ }^{59}$ The cancellation fee clause was separate from the security deposit provision and entitled Cedar Ridge to $\$ 474$ for Wurtz's premature termination of the lease. ${ }^{60} \mathrm{~A}$ cancellation fee is a type of liquidated damages if it stipulates an amount, agreed upon by the parties, to be paid in the event of breach. ${ }^{61}$ The legality of a cancellation fee clause in a residential lease would have been a matter of first impression, but the Court of Appeals noted that, because Cedar Ridge failed to cross-appeal at the district court level, the question of its enforceability was not properly preserved for appeal. ${ }^{62}$

59. See id. at 303 ("Cedar Ridge failed to preserve for appeal the issue of cancellation fee provisions in the lease agreement.").

60. Id. at 301 .

61. See Kvassay v. Murray, 808 P.2d 896, 900-01 (Kan. Ct. App. 1991) (analyzing a liquidated-damage clause in a manufacturing contract); Unified Sch. Dist. No. 315, Thomas County v. DeWerff, 626 P.2d 1206, 1208 (Kan. Ct. App. 1981) (noting "[a] stipulation for damages upon a future breach of contract is valid as a liquidated damages clause if the set amount is determined to be reasonable and the amount of damages is difficult to ascertain"); SAMUEL WILLISTON \& RICHARD A. LORD, A TREATISE ON THE LAW OF CONTRACTS $\$ 65: 1$ (4th ed. 2002) (discussing the validity of liquidated-damage clauses in contracts); Gregory Scott Crespi, Measuring "Actual Harm" for the Purpose of Determining the Enforceability of Liquidated Damages Clauses, 41 Hous. L. REV. 1579, 1579-80 (2005) (noting "[a] contractual provision stipulating a sum of money to be paid as damages in the event of breach will be enforced as a valid liquidated damages clause in most U.S. jurisdictions" subject to certain requirements); Henry F. Luepke III, How to Draft and Enforce a Liquidated Damages Clause, 61 J. Mo. B. 324, 324 (2005) ("Parties to contract are free to stipulate to an amount certain that, in the event of breach, the non-breaching party shall recover in lieu of actual damages."); Paul Bennett Marrow, The Unconscionability of a Liquidated Damage Clause: $A$ Practical Application of Behavioral Decision Theory, 22 PACE L. REV. 27, 33 (2001) ("A liquidated damage clause .. . quantifies and assigns risk associated with a default by any party to a contract."). See also infra text accompanying notes $65-87$ for a discussion of the tests Kansas courts employ to distinguish allowable liquidated-damage clauses from illegal penalty provisions.

62. Wurtz, 18 P.3d at 304. An appeal from small claims court "shall be tried and determined de novo before a district judge." KAN. STAT. ANN. § 61-2709(a) (2005). Though Cedar Ridge failed to cross-appeal the small claims judgment that denied enforcement of the lease's cancellation fee, at 
Though the court in Wurtz clearly stated that liquidated damages or a lump sum penalty are not permissible within the security deposit provision of the $\mathrm{KRLTA}_{,}{ }^{63}$ the question still remains as to whether a cancellation fee, separate from a security deposit clause, may be enforceable under the Act.

While the court in Wurtz did not address the legality of a separate liquidated damages clause, cancellation fee provisions continue to be included in residential leases despite some question as to their enforceability. A review of relevant Kansas statutes and case law reveals arguments for and against enforcing such liquidated damages clauses in residential leases, but unfortunately provides no clear answer as to whether they will withstand judicial scrutiny.

One argument for enforcing a cancellation fee is that, because the lease is a contract, Kansas law permits inclusion of such provisions as long as the cancellation fee is structured as liquidated damages and not as an illegal penalty. ${ }^{64}$ This argument requires a further look at the nature of Kansas contract law, specifically at how the courts characterize liquidated damages and penalty clauses. In two particular Kansas cases, the Court of Appeals has provided comprehensive overview of the distinction between liquidated damages clauses and penalties in other contractual contexts.

In the first case, Unified School District No. $315 v$. DeWerff, ${ }^{65}$ the appellate court addressed whether a clause included in a teacher's employment contract was a valid liquidated damages clause or an illegal penalty. ${ }^{66}$ Granted, DeWerff dealt with interpretation of an employment contract and not a residential lease, but the court provided a detailed discussion of the nuances of liquidated damages and penalty clauses generally ${ }^{67}$ Much can be gleaned from the DeWerff opinion that may be extended by analogy to the landlord-tenant context. ${ }^{68}$

oral argument it contended it was not required to do so under section 61-2709(a). Wurtz, 18 P.3d at 304. This procedural issue was a matter of first impression for the court. The court held that, because the district judge sits as an "appellate court" in instances where there is a direct appeal from a small claims judgment, the proceeding is "predominantly appellate in nature." $I d$. Therefore, Cedar Ridge should have formally appealed the issue of enforceability of the cancellation fee.

63. Id. at 302 (citing Vogel v. Haynes, 730 P.2d 1096, 1097 (Kan. Ct. App. 1986)).

64. See supra note 61 (discussing the validity of liquidated-damage clauses in contracts).

65. 626 P.2d 1206 (Kan. Ct. App. 1981).

66. Id. at 1207 .

67. Id. at $1208-10$.

68. Cf. John Deere Leasing Co. v. Blubaugh, 636 F. Supp. 1569, 1570, 1572 (D. Kan. 1986) (addressing the issue of "unconscionability" in a contract for the sale of goods). In discussing Kansas law regarding the doctrine of unconscionability, the Blubaugh court cites illustrative Kansas cases and states that the doctrine of unconscionability under the U.C.C. has been "extended by analogy to other areas of law." Id. 
In DeWerff, a local school district in Kansas sought to enforce a contractual provision against a teacher (and basketball coach) who resigned after the contract was signed, but before the school year began. ${ }^{69}$ The clause at issue provided that:

in all cases where a teacher who is under contract fails to honor the full term of his or her contract, a lump sum of $\$ 400.00$ be collected between contract acceptance and August 1 if contract is broken. After August 1 a penalty of $\$ 75.00$ will be charged for each full or part of a month remaining on his or her contract.

When the teacher, DeWerff, resigned before the school year began, the school district invoked the language of the employment contract, demanding that he pay the $\$ 400 .^{71}$ DeWerff refused to pay, resulting in the school district filing a suit to enforce the contract. ${ }^{72}$ The district court ruled in favor of the school district, finding the contractual provision to be a valid liquidated damages clause and determining that the $\$ 400$ amount was reasonable. ${ }^{73}$

On appeal, DeWerff argued that the clause was unenforceable because it was an illegal "penalty.", In determining whether the contract provision was enforceable, the Kansas Court of Appeals began its analysis by stating:

It is well settled that parties to a contract may stipulate to the amount of damages for breach of the contract, if the stipulation is determined to be a liquidated damages clause rather than a penalty. A stipulation for damages upon a future breach of contract is valid as a liquidated damages clause if the set amount is determined to be reasonable and the amount of damages is difficult to ascertain.

Moreover, the court noted, the difference between a liquidated damages clause and a penalty is that "a penalty is to secure performance, while a

69. See DeWerff, 626 P.2d at 1207 (stating that the defendant, after being employed by the school district for many years, gave notice of his resignation on June 28, 1978).

70. Id. at 1208 (emphasis added).

71. Id. at 1207 .

72. Id.

73. Id. at 1208 .

74. Id.

75. Id. (citing White Lakes Shopping Ctr., Inc. v. Jefferson Standard Life Ins. Co., 490 P.2d 609, 613-15 (Kan. 1971); Beck v. Megli, 114 P.2d 305 (Kan. 1941); R.R. Co. v. Gaba, 97 P. 435 , 436-37 (Kan. 1908)) (emphasis added). In DeWerff, the court of appeals noted that the teacher did not challenge the district court's ruling that the amount of agreed upon damages ( $\$ 400)$ was reasonable and not excessive. DeWerff, 626 P.2d at 1210 . 
liquidated damages provision is for payment of a sum in lieu of performance." 76

The court rejected DeWerff's argument that the contract clause's reference to the $\$ 400$ amount as a "penalty" was determinative. It held that use of the term "penalty" throughout the contract was insufficient to defeat the district court's finding that the clause was a liquidated damages clause. ${ }^{77}$ Instead, in determining whether to treat a contractual provision as liquidated damages or a penalty, a court must look at the facts before it and the underlying nature of the parties' transaction. ${ }^{78} \mathrm{~A}$ contract clause will be deemed "a penalty where there is no attempt to calculate the amount of actual damages that might be sustained in case of breach." 79

The other Kansas case assessing the validity and enforceability of liquidated damages, Kvassay v. Murray, ${ }^{80}$ arose in the Uniform Commercial Code (U.C.C.) context. $^{81}$ It involved the sale of baklava between two merchants. ${ }^{82}$ In assessing whether the seller of baklava would be allowed to enforce a liquidated damages clause that entitled it to collect damages of five dollars per case of baklava if the buyer "refuses to accept or repudiates the goods sold," the Kansas Court of Appeals applied only a reasonableness test. ${ }^{83}$ The court stated that under the U.C.C., codified at chapter 84 of the Kansas Statutes, it was not necessary to apply the two-part test (reasonableness and difficulty in ascertaining damages) articulated under DeWerff. ${ }^{84}$ Instead, the court focused on three criteria provided within the U.C.C. to measure reasonableness. ${ }^{85}$ The three criteria are: "(1) anticipated or actual harm

76. Id. at 1208 (citing Erickson v. O'Leary, 273 P. 414, 414-15 (Kan. 1929)); see also Gregory v. Nelson, 78 P.2d 889, 892-93 (Kan. 1938) (finding a contract provision, which declared an advance payment could be kept by a vendor if the vendee defaulted, was a liquidated-damage clause and enforceable); Kuter v. Bank, 152 P. 662, 664 (Kan. 1915) (finding a contract provision, which fixed the measure of damages at a certain amount and required both parties to deposit that amount for a bank to hold until the terms are satisfied, was security for enforcement of the contract and not a penalty).

77. DeWerff, 626 P.2d at 1208 . But see the dissent, which disagreed with other members of the court about the use of the term "penalty." Id. at 1211 (Abbott, J., dissenting). The dissent stressed the purpose and intent of the parties, which was to impose a penalty for the breach of the employment contract. This intent was clearly articulated in the contract; therefore, the use of the term "penalty" within the contract cannot be discounted. $I d$.

78. Id. at 1208 (majority opinion).

79. Id. at 1209 (citing Gregory, 78 P.2d at 892).

80. 808 P.2d 896 (Kan. Ct. App. 1991).

81. Id. at 900 .

82. Id. at 899 .

83. Id. at $900-01$.

84. Id. at 900 .

85. Id. (citing KAN. STAT. ANN. § 84-2-718 (1996)) 
caused by breach; (2) difficulty of proving loss; and (3) difficulty of obtaining an adequate remedy." test, the court remanded the case to the district court to determine reasonableness in light of the three criteria. ${ }^{87}$

Though the Court of Appeals sets out separate tests in DeWerff and $K$ vassay to determine whether liquidated damages are allowable within their respective contexts, in effect, the tests are nearly identical when translated into the landlord-tenant context. Both cases appear to simply suggest that, if a cancellation fee provision in a residential lease includes an agreed upon amount that is reasonable and if the landlord can demonstrate that, as a result of the tenant's breach, the amount of damages is difficult to determine, then the cancellation fee provision will be considered an enforceable liquidated damages clause. Whether a court employs the DeWerff two-part test or the Kvassay reasonableness test should make no practical difference in assessing the validity of a liquidated damages clause in a lease as long as the court considers the relevant facts and circumstances surrounding the lease agreement. Thus, there is no bright-line test for resolving whether cancellation fee clauses are enforceable. Instead, the courts must make a determination as to their enforceability on a case by case basis. Indeed, DeWerff and $K$ vassay also demonstrate that the distinction between a valid liquidated damages provision, which is enforceable under Kansas contract law, and a penalty provision, which is void as illegal, may be difficult to make.

Another argument for enforcing cancellation fee provisions in residential leases is that they are not expressly prohibited by the KRLTA. Section 58-2545(a) states that parties to a residential lease agreement may include "terms and conditions not prohibited" by the Act or other rule of law. ${ }^{88}$ Section 58-2547 lists four provisions that a landlord and tenant may not agree to in a residential lease. ${ }^{89}$ Specifically, the statute prohibits: (1) an agreement to waive or forego rights or remedies under the KRLTA; (2) an automatic confession of judgment provision; (3) a payment of attorney's fees clause; and (4) an exculpation or limitation of liability provision. ${ }^{90}$ The landlord's inclusion of any of these provisions in a lease may entitle the tenant to recover actual damages. ${ }^{91} \mathrm{~A}$ cancellation fee clause is not included in the list of prohibited terms, and

86. Id.

87. Id. at 901 .

88. KAN. STAT. ANN. \$ 58-2545(a) (2005).

89. KAN. STAT. ANN. § 58-2547 (2005).

90. Id.

91. Id. $\$ 58-2547(\mathrm{~b})$. 
so may arguably be permitted under the Act as long as the agreed upon amount is reasonable and is not deemed unconscionable as a matter of law under section 58-2544. ${ }^{92}$

A third argument that may support enforcement of liquidated damages clauses is weaker than the first two arguments. The Vogel court intimates that a cancellation fee in a residential lease may be permissible and enforceable so long as it is separate from the security deposit provision. $^{93}$ In Vogel, the landlord unsuccessfully argued that the lease provision allowing him to keep the tenant's $\$ 110$ deposit because of the tenant's failure to remain in the apartment for a full year was a liquidated damages clause, not a security deposit provision governed by section 58 2550 (b)..$^{94}$ Referring to the specific language of that lease provision, the Vogel court rejected the landlord's argument, stating "[w]e find no language common to liquidated damage clauses," and enforced the provision as a security deposit clause. ${ }^{95}$ The court's comment concerning the absence of specific liquidated damages language in the lease is a subtle suggestion that, should the landlord have included a separate clause structured as a liquidated damages clause, it may have been enforceable. Moreover, in Vogel, the landlord sought to retain the tenant's security deposit because of the tenant's breach. A liquidated damages clause structured to allow the landlord to collect, rather than keep, a reasonable amount of money for the tenant's breach might be permissible.

Lastly, Kansas courts have determined that a late fee, charged to a tenant for failure to pay rent when due, is permissible under the Act. ${ }^{96}$ Yet, the KRLTA does not explicitly permit the landlord to assess such damages to the tenant. Like a cancellation fee, a late fee is a form of liquidated damages because it is an agreed upon amount between the parties that the tenant must pay in the event the tenant breaches-that is, does not pay rent in a timely fashion. Kansas courts have determined

92. See KAN. STAT. ANN. § 58-2544(a) (2005) (stating a court may refuse to enforce an unconscionable lease term or the entirety of a lease containing an unconscionable lease provision); see also Heckard v. Martin, 958 P.2d 665, 668 (Kan. Ct. App. 1998) (finding charges for late rent payments recoverable unless they are unconscionable); infra text accompanying notes $100-03$ (discussing unconscionability under Kansas law). For a discussion of the application of the doctrine of unconscionability to various contracts, see Wille v. Southwestern Bell Telephone Co., 549 P.2d 903, 903-11 (Kan. 1976).

93. See Vogel v. Haynes, 730 P.2d 1096, 1098-99 (Kan. Ct. App. 1986) (holding that a landlord could not withhold a security deposit from an early vacating tenant because the landlord did not provide an itemized list of damages to the tenant).

94. Id. at 1098 .

95. Id.

96. E.g., Clark v. Walker, 590 P.2d 1043, 1051 (Kan. 1979); Heckard, 958 P.2d at 668. 
that as long as the late fee is reasonable, it may be included in a residential lease and enforced. ${ }^{97}$ Though a landlord is permitted to collect a late fee from the tenant, it is possible the courts view a late fee, which have not exceeded ten dollars in cases where courts have reviewed them, as negligible and not as liquidated damages.

If late fees are permissible and enforced under the KRLTA, then why wouldn't a cancellation fee be enforceable if a tenant prematurely terminates the lease? The answer may be that inclusion of liquidated damages such as a cancellation fee, in addition to a landlord's right to collect a late fee, goes well beyond the boundaries of reasonableness. At some point the landlord's stacking or inclusion of liquidated damages clauses for every conceivable tenant breach becomes apparently onesided and punitive. Arguably, these clauses would be unenforceable because, in combination and in total, they rise to the level of unconscionability and are deemed void as a penalty.

The arguments against enforcement of liquidated damages clauses in residential leases appear as convincing as those arguments in favor of enforcement. One argument against enforcement of liquidated damages clauses is that a cancellation fee clause may be unconscionable under section 58-2544 of the KRLTA. Under this statutory provision, a court may as a matter of law refuse to enforce an unconscionable term or, in its discretion, refuse to enforce the entire lease if an unconscionable term or terms exist in the residential lease. ${ }^{98}$ The statute further provides that if either party or the court on its own motion raises the issue of unconscionability, the parties shall be afforded the opportunity to present evidence so the court can make its determination. ${ }^{99}$

Unconscionability, like reasonableness, is not formally defined under the KRLTA, but Kansas courts have explored the common law doctrine of unconscionability in many contractual contexts. ${ }^{100}$ Along with being codified in the KRLTA, the doctrine of unconscionability is mentioned in the Uniform Consumer Credit Code (section 16a-5-108 of the Kansas Statutes) and the Consumer Protection Act (section 50-627 of the Kansas Statutes). ${ }^{101}$ What constitutes unconscionability often depends on the totality of the facts and circumstances surrounding the contractual

97. Heckard, 958 P.2d at 668 .

98. KAN. STAT, ANN. § 58-2544 (2005).

99. Id.

100. See Wille v. Sw. Bell Tel. Co., 549 P.2d 903, 906 (Kan. 1976) (discussing application of the doctrine of unconscionability to various contracts).

101. Id. 
agreement between the parties. ${ }^{102}$ In the landlord-tenant context, examples of relevant factors that a court may consider in determining unconscionability might include: (1) boilerplate language that the landlord, who may be in a stronger economic position than the tenant, incorporates into a lease; (2) a significant or excessive fee for the tenant's breach of the lease; (3) inclusion of clauses that are clearly penalties or punitive in nature; (4) the circumstances leading up to the execution of the lease; (5) the hiding of unfair or disadvantageous clauses within the lease that adversely affect the tenant; (6) the use of incomprehensible language within the lease; $(7)$ the overall imbalance of the rights and obligations of each party to the lease; and (8) the lease's exploitation of the undereducated, illiterate, or unsophisticated tenant. ${ }^{103}$ It may be the case under this analytical approach that no per se rule against prohibiting enforcement of cancellation fee clauses exists. Rather, the enforceability of cancellation fee clauses must be determined case by case.

A second argument against enforcement of cancellation fee clauses is the converse of an argument supporting the enforcement of cancellation fee clauses. As already mentioned, the KRLTA lays out the basic parameters of the landlord-tenant relationship and does not explicitly mention liquidated damages clauses. The Act's silence on liquidated damages might suggest that a cancellation fee provision or other liquidated damages clause, which allows the landlord to collect rather than retain money for actual damages from a tenant for conditions beyond what the Act explicitly provides, may not be allowable, although the Act does permit the landlord and tenant to include other terms and conditions not prohibited by the KRLTA or other rule of law. Indeed, it may be that courts draw a distinction between allowing a landlord to include lease terms which allow the landlord to retain money paid by the tenant for a security deposit and allowing a landlord to collect damages for a tenant breach.

The statutory framework of the KRLTA itself further supports this argument, specifically subsections (b) and (d) of section 58-2550, both of which detail the treatment of the security deposit at the end of the

102. Id.

103. See id. at $906-07$ (discussing unconscionability generally). In another case, the lessor of a combine filed suit in federal court to recover damages from a lessee arising from the repossession and sale of a combine. The federal district court held that the liquidated-damage clause included in the lease, and entitling the lessor to collect $\$ 12,054.43$ from the lessee as a deficiency from the resale of the combine, was unconscionable and therefore unenforceable. John Deere Leasing Co. v. Blubaugh, 636 F. Supp. 1569, 1570-75 (D. Kan. 1986). 
tenancy. ${ }^{104}$ The language of section 58-2550(b) expressly provides that the landlord may only deduct damages and accrued rent from the security deposit. ${ }^{105}$ The Kansas Court of Appeals has interpreted this statutory provision to permit the landlord to apply part or all of a security deposit to accrued rent and actual damages. ${ }^{106}$ Moreover, the court has also held that any other conditions placed on return of the security deposit which entitle the landlord to retain any or all of the security deposit as a result of the tenant's breach are liquidated damages clauses and not permissible under the security deposit provisions of the Act. ${ }^{107}$ The language of section 58-2550(d) is similarly restrictive. It allows for forfeiture of the tenant's security deposit if the tenant attempts to apply the security deposit to rent at any time during the tenancy, so long as the lease clearly includes this forfeiture language. ${ }^{108}$ When interpreting the subsections in light of each other, there is strong indication that the Act only allows forfeitures of this specific type. Therefore, it is conceivable that allowing the landlord to collect damages of any other kind or for any other tenant breach is not permissible because it is not explicitly provided for under the Act. ${ }^{109}$

A final argument against enforcing liquidated damages clauses, such as cancellation fee provisions, against tenants rests squarely on section 58-2565, which requires the landlord to "make reasonable efforts to rent [the leased premises] at a fair rental" if the "tenant abandons the dwelling unit." 110 In a situation where the tenant has abandoned or voluntarily surrendered the rental property prior to expiration of the lease agreement, the statute requires the landlord to mitigate any damages as result of the tenant's premature termination of the landlord-tenant relationship. Therefore, the landlord's immediate enforcement of the cancellation fee against the tenant obviates the statutory mandate that the landlord mitigate damages. As such, the tenant who finds himself in the

104. KAN. STAT. ANN. $§ 58-2550(\mathrm{~b})$, (d) (2005).

105. Id. §58-2550(b).

106. See Vogel v. Haynes, 730 P.2d 1096, 1098 (Kan. Ct. App. 1986) (emphasis added).

107. Id.

108. KAN. STAT. ANN. § 58-2550(d); see also Clark v. Walker, 590 P.2d 1043, 1050 (Kan. 1979) (stressing that the lease must include clear forfeiture language in order for the landlord to treat the security deposit as forfeited under section $58-2550(\mathrm{~d})$ ).

109. Though the Kansas courts have created an exception with regard to late fees, it is arguable that the late fee, in most cases not exceeding ten dollars, is negligible and is not viewed as liquidated damages.

110. KAN. STAT. ANN. \$ 58-2565 (2005). Subsection (b) of section 58-2565 allows the landlord to enter the dwelling at times reasonably necessary if the tenant is absent from the unit in excess of thirty days. Also, this subsection provides that if the tenant is ten days in default for nonpayment of rent and has taken a substantial portion of his belongings, the landlord may treat the dwelling as abandoned. Id. 
unfortunate position of being assessed a reasonable cancellation fee for premature termination of a lease may successfully argue that the landlord must prove his reasonable efforts to lease the rental property before a cancellation fee can be assessed.

Thus, it remains unresolved whether liquidated damages clauses, such as cancellation fee provisions found in residential leases, are enforceable. Arguably, liquidated damages may be permissible in a residential lease, provided they are not unconscionable and do not relate to the tenant's security deposit. Indeed, whether a cancellation fee or other lump sum payment clause included in residential leases is enforceable in court may rest on whether the amount provided in the liquidated damages clause is reasonable and does not rise to the level of unconscionability. It may also depend largely on the particular facts and circumstances surrounding the lease agreement and on whether the courts will draw a distinction between a landlord's proper withholding of a security deposit and the landlord's right to collect reasonable damages for a tenant's breach.

\section{Landlord's Substantial Compliance in Return of the Tenant's Security Deposit: A Rare Defense to Civil Penalties}

A few years after Wurtz, the Kansas Court of Appeals again dealt with a landlord's wrongful withholding of a tenant's security deposit, this time in a different context. In A\&S Rental Solutions, Inc. v. Kopet, ${ }^{111}$ the court addressed whether strict compliance is required in returning a tenant's security deposit under section 58-2550(b) of the KRLTA. ${ }^{112}$ The original tenants, George Lien and Julie McEnaney, who paid the $\$ 900$ security deposit at the beginning of their tenancy, subleased the rental property to third parties, Terance and Jodie Kopet. ${ }^{113}$ The landlord, A\&S, acquiesced to the sublease. Moreover, with the agreement of Lien and McEnaney, A\&S retained their original security deposit of $\$ 900$ in order to ensure the performance of the sublessees, the Kopets. ${ }^{114}$

At the end of the sublease, A\&S sought to return the security deposit to its rightful owner. Unsure whether the original lessees or the sublessees were rightly entitled to the amount, A\&S filed a petition for

111. 76 P.3d 1057 (Kan. Ct. App. 2003).

112. Id.

113. Id. at 1058

114. Id. 
declaratory judgment. ${ }^{115}$ A\&S also sought back rent and damages from the Kopets in its petition. ${ }^{116}$ By the time a hearing was held on the landlord's petition, more than thirty days had lapsed since the Kopets vacated the rental property. ${ }^{117}$ The district court issued an order finding the Kopets liable for unpaid rent and ordering the balance of the security deposit, $\$ 215$, to be paid to Lien and McEnaney, the original tenants. ${ }^{118}$ Moreover, the district court determined that A\&S wrongfully withheld the security deposit from Lien and McEnaney and assessed a civil penalty of one and one-half times the amount wrongfully withheld under section 58-2550(c). ${ }^{119}$ In making its decision to assess the civil penalty against A\&S, the district court relied on Love v. Monarch, ${ }^{120}$ a case where the Kansas Court of Appeals held that a trial court shall assess a civil penalty under section 58-2550(c) if the tenant is successful in recovering part or all of the security deposit from the landlord. ${ }^{121}$

The only issue reviewed on appeal was whether the district court erred in assessing the civil penalty under section 58-2550(c). ${ }^{122}$ The Kansas Court of Appeals held that the district court erred in relying on Love as authority for the assessment of a civil penalty on the landlord. ${ }^{123}$ The court reasoned that, while Love provides that a trial court has no discretion whether to assess the penalty when the landlord wrongfully withholds a tenant's security deposit, the $A \& S$ case was distinguishable because two different parties claimed ownership of the security deposit. ${ }^{124}$ More significantly, the court noted that the landlord's petition for declaratory judgment sought determination of the rightful ownership of the security deposit and demonstrated the landlord's earnest efforts to comply with section 58-2550(b). ${ }^{125}$ Ultimately, the court determined that the landlord's affirmative and good faith efforts in filing the petition for declaratory judgment equaled substantial compliance. ${ }^{126}$ Thus, the Court of Appeals held that, because the landlord sought to follow the directive

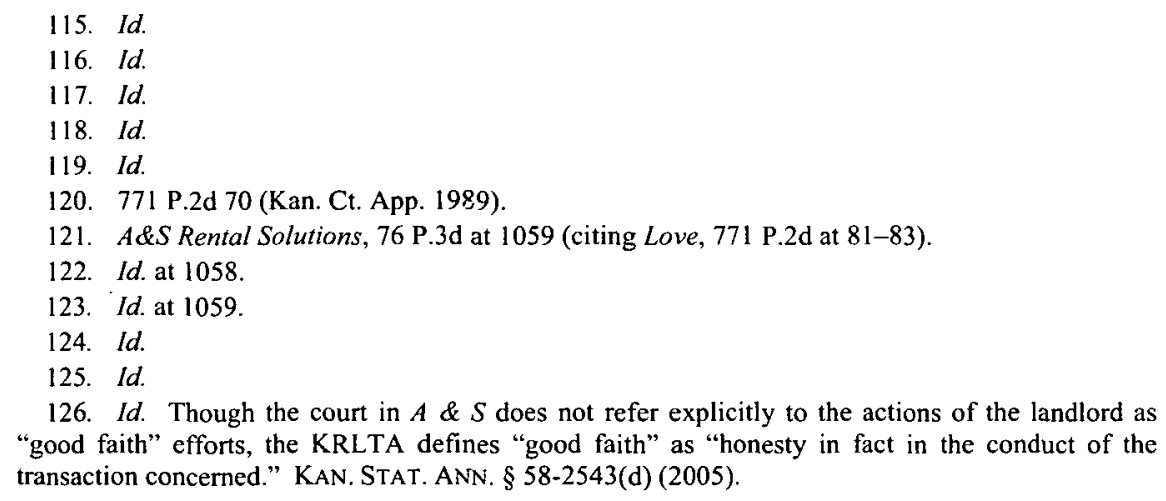
"good faith" efforts, the KRLTA defines "good faith" as "honesty in fact in the conduct of the transaction concerned." KAN. STAT. ANN. § 58-2543(d) (2005). 
of the statute, the trial court erred in assessing the civil penalty against A\&S. ${ }^{127}$

The result in $A \& S$ was probably appropriate considering the unique facts of the case and the landlord's efforts to determine rightful ownership of the security deposit and ensure its proper return. However, it is important to note that, as a general matter, many states, including Kansas, mandate that landlords strictly comply with their respective statutes concerning proper return of a tenant's security deposit. Otherwise, a landlord is precluded from retaining all or any portion of the deposit. In some states, like Kansas, a landlord is assessed statutory damages for wrongful withholding. ${ }^{128}$ Moreover, the $A \& S$ court stressed that its decision to set aside the trial court's assessment of the civil penalty was based on the specific facts of the case and therefore did not create a generally applicable substantial compliance exception to the landlord's duty to comply with section 58-2550(b). ${ }^{129}$

\section{Recovery of Late Fees in Residential Agreements}

The KRLTA does not specifically mention or discuss the enforceability of late fees in a residential lease, but the Kansas Supreme Court had the opportunity to address them as early as 1979. In Clark v. Walker, the tenants, wary the landlord would not return their security deposit at the end of their tenancy, refused to pay their last month's rent when it became due, insisting the landlord apply their $\$ 200$ security

127. A\&S Rental Solutions, 76 P.3d at 1060.

128. See KAN. STAT. ANN. § 58-2550(c) (2005). In Garcia v. Tharg, 895 P.2d 226 (N.M. 1995), the landlord refused to refund the tenant's security deposit and failed to provide the tenant with an accounting explaining why she withheld the security deposit. Id. at 227. The New Mexico Supreme Court held that, because the landlord failed to comply with section 47-8-18(c) of the state's Uniform Owner-Resident Relations Act, she forfeited her right to retain any portion of the security deposit and was precluded from filing any suit for alleged damages under the Act. The court also ordered the landlord to return the full security deposit to the tenant and to pay the tenant's attorney's fee. Id. at 229; see also Lloyd T. Wilson, Jr., Fulfilling the Deterrent and Restitutionary Goals of the Security Deposits Statute and Other Developments in Indiana Property Law, 35 IND. L. REV. 1501, 1503-18 (2002) (discussing whether the Indiana Security Deposits statute requires "strict compliance" or whether it permits "substantial compliance" by the landlord); Residential Landlord/Tenant Disputes: Parties' Rights, Obligations, and Remedies, Chapter VII, Security Deposits and Advance Rent, 2006 FLA. B. FASTRAIN 31, 33 (noting that, under Florida law, the landlord must strictly comply with the requirements of the security deposit statute or forfeit any claim to the deposit).

129. A\&S Rental Solutions, 76 P.3d at 1059-60. In $A \& S$, the court explained that the purpose of the civil penalty statute would not be served by imposing such a penalty because, in that case, the landlord had not simply refused to return the security deposit; rather, the landlord withheld the deposit only while a declaratory action determining to whom the deposit belonged was pending. Id.; see also supra text accompanying notes 125-27. 
deposit toward their monthly rent of $\$ 210 .{ }^{130}$ When the rent came due, the tenants tendered a check for ten dollars, so the total monthly rent was ostensibly paid. ${ }^{131}$ The landlord refused to apply the security deposit as rent and also refused to accept the tenants' ten dollar check, claiming that, per the lease, the tenants were precluded from applying the security deposit toward their last month's rent. ${ }^{132}$ When the landlord filed suit to recover unpaid rent and seek forfeiture of the tenants' security deposit, one of the issues raised on appeal was whether the landlord could collect a ten dollar late fee for the tenants' failure to pay rent in a timely manner. ${ }^{133}$ The court determined that the tenants' attempt to apply the security deposit toward the last month's rent and their tender of ten dollars did not constitute payment of rent under the lease. ${ }^{134}$ Therefore, the court held, the district court should have enforced the late fee provision against the tenants. ${ }^{135}$

Almost twenty years after Clark, the Kansas Court of Appeals again addressed whether the landlord could recover late fees under the KRLTA in Heckard v. Martin. ${ }^{136}$ In Heckard, the otherwise uneventful two-year relationship between the landlord, Robert W. Heckard, and the tenants, Andrew and Stacy Martin, ended badly after the Martins withheld rent because Heckard refused to make requested repairs to their leased duplex. ${ }^{137}$ When the Martins refused to pay rent and provided a thirtyday notice of their intent to terminate the lease, Heckard gave them a three-day notice to pay rent or vacate. ${ }^{138}$ Soon thereafter, Heckard filed an eviction proceeding against the Martins seeking back rent and statutory damages pursuant to section 58-2570(c) of the KRLTA, claiming the Martins were willful holdovers. ${ }^{139}$

\footnotetext{
130. Clark v. Walker, 590 P.2d 1043, 1045 (Kan. 1979).

131. Id.

132. Id. at $1045-46$.

133. Id. at 1051 .

134. Id.

135. Id. The Clark court reversed and remanded the case with directions. Id. Other states have similarly enforced late-fee provisions against tenants. See Krupp Realty Co. v. Joel, 309 S.E.2d 641 , 644 (Ga. Ct. App. 1983) (holding a "\$50 late charge should have been included in the trial court's award of rent"); Nylen v. Park Doral Apartments, 535 N.E.2d 178, 184 (Ind. Ct. App. 1989) ("[T]he trial court properly awarded late fees for the balance of the term."); Borne v. Wilander, 509 So. 2d 572, 573 (La. Ct. App. 1987) (upholding imposition of late payment penalty); cf. Highgate Assocs., Ltd. v. Merryfield, 597 A.2d 1280, 1284 (Vt. 1991) (holding that a five-dollar late fee imposed after the sixth day of the month plus one dollar for each additional day the rent was late was not a valid liquidated-damage provision but rather an unenforceable penalty).

136. 958 P.2d 665, 668 (Kan. Ct. App. 1998).

137. Id. at 666 .

138. Id.

139. Id.
} 
On appeal, Heckard argued that he was entitled to collect late charges pursuant to the lease, amounting to ten dollars, because the Martins did not pay their rent in a timely manner. ${ }^{140}$ Because the KRLTA does not specifically allow for late fee provisions, the court looked at whether late fees fit the statutory definition of recoverable "rent". ${ }^{141}$ Under section 58-2543(j), "rent" is defined as "all payments to be made to the landlord under the rental agreement, other than the security deposit." 142 The court determined that the definition of "rent" allows the landlord to recover late fees in an eviction proceeding provided that the late fee is not unconscionable under section 58-2544 and as long as the landlord specifically requests the late charges in the eviction petition. $^{143}$ In Heckard, however, the landlord failed to specifically request late fees in his eviction petition, and therefore was not entitled to recover them. ${ }^{144}$ Thus, if a residential lease provides for a late fee and the landlord wants to recover such fee in an eviction action, the landlord must include the request in the petition. Otherwise, late fees are not recoverable.

\section{E. Definition of and Consequences Arising from Willful Holdover by Tenant}

In Heckard, the Kansas Court of Appeals also addressed whether the tenants' refusal to pay rent while remaining in the duplex as holdovers rose to the level of "willfulness" under section 58-2570(c), the Act's holdover provision. ${ }^{145}$ The statute provides that a landlord may recover damages of not more than one and one-half months' rent or not more than one and one-half times the actual damages sustained by the landlord, whichever is greater, if the tenant's holdover is "willful and not in good faith."146 The court affirmed the district court's finding that the Martins' actions in remaining in the duplex were not "willful," noting that the landlord failed to meet his statutory obligations under section 582553, which required him to address the requested repairs that "materially affected the safety of his tenants." 147 The court stated that a

140. Id. at 668 .

141. Id. Interestingly, in Heckard, the Kansas Court of Appeals analyzed the issue of late fees and did not refer to the 1979 Kansas Supreme Court decision in Clark.

142. KAN. STAT. ANN. $\S 58-2543(j)$ (2005).

143. Heckard, 958 P.2d at 668.

144. Id.

145. Id. at 667 .

146. KAN. STAT. ANN. $§ 58-2570$ (c) (2005).

147. Heckard, 958 P.2d at 667 (quoting KAN. STAT. ANN. $\S \S 58-2553,-2570(\mathrm{c})$ ) 
willful action is one " with a designed purpose or intent on the part of a person to do wrong or to cause an injury to another." ${ }^{\prime 148}$ In this case, the Martins' actions in refusing to pay rent but remain in the duplex were not intended to harm the landlord, but were, instead, futile attempts to encourage Heckard to make the requested and necessary repairs. ${ }^{149}$

\section{STATUTORY ChANGES: THE KRLTA AND THE Eviction STATUTE}

Since the KRLTA was codified in 1975, the statute has undergone a few minor changes. In the last ten years or so, the only addition to the Act has been section 58-2570(e), which was enacted in 2005 . It addresses the landlord's duty to include a notice requirement in any document the landlord issues the tenant that may bind the tenant to terms beyond the original lease agreement. ${ }^{150}$ A discussion of section 582570(e), some notable Kansas legislative activity relating to other proposed changes to the KRLTA, and a few legislative amendments pertaining, and relevant to, the Eviction statute are discussed below.

\section{A. The Addition of Section 58-2570(e) to the KRLTA and Proposed Legislative Limitations on Automatic Lease Renewal Clauses}

After mounting pressure from tenants and tenant's associations, during the 2003 legislative session, the Kansas legislature added a new provision, section 58-2570(e), to the KRLTA. This additional provision deals with documents or notices the landlord provides to the tenant which relate to a tenant's intent to vacate a rental property. ${ }^{151}$ The new statutory language stems from a need to address the common practice among landlords of providing tenants with a document to sign toward the end of the tenancy, which ostensibly is a tenant's notice to the landlord of his intent to vacate the rental property. However, these documents usually include additional terms such as language that binds the tenant to another lease term if the tenant does not sign the notice to vacate on or before a prescribed time. Before the amendment, if the tenant did not read the document carefully or did not fully comply with its terms, the obvious consequence was that these terms unexpectedly bound him to

148. Id. at 667 (quoting KANSAS JUdiCIAL COUNCIL, PATTERN INSTRUCTIONS KANSAS 3d 10305 (Thomson West 2005)).

149. Id. at $667-68$.

150. KAN. STAT. ANN. $\$ 58-2570(\mathrm{e})$.

151. See id. (requiring a notice signed by landlord, tenant, or both with specific notice of the changes to a lease). 
additional obligations beyond the original lease. The new amendment to the KRLTA, section 58-2570(e), states that if the landlord provides a document to the tenant that includes any additional language not contained in the original lease agreement, then the document must include the following language in no less than ten-point boldface type: "YOUR SIGNATURE ON THIS DOCUMENT MAY BIND YOU TO ADDITIONAL TERMS NOT IN YOUR ORIGINAL LEASE AGREEMENT. IF YOUR LEASE REQUIRES YOU TO GIVE WRITTEN NOTICE OF YOUR INTENT TO VACATE, YOU HAVE A RIGHT TO DECLINE TO SIGN THIS DOCUMENT AND TO PROVIDE WRITTEN NOTICE IN ANOTHER FORM." 152

Being a fairly recent addition to the KRLTA, no Kansas cases have addressed section 58-2570(e), nor are there any decisions from other states that provide guidance in this area. Hopefully, the above proviso printed in boldface type will catch the attention of the unsuspecting tenant who ignores or otherwise fails to carefully read documents that a landlord frequently issues to the tenant as the end of the tenancy nears.

A related problem is the automatic lease renewal clause, a provision which a landlord includes in the original lease with the tenant. ${ }^{153}$ This type of clause states conditions that the tenant must meet prior to the lease expiring, such as providing the landlord with a thirty-day notice of the tenant's intent to vacate the leased premises. ${ }^{154}$ In some leases, these clauses require the tenant to notify the landlord of his intent to vacate sixty or ninety days before the expiration of the original lease. ${ }^{155}$ The tenant's failure to meet the notice obligation results in automatic renewal of the lease for an additional period, or in the alternative, the tenant's payment of specified liquidated damages to the landlord. ${ }^{156}$

To date, no Kansas case addresses the legality of the automatic lease renewal clause, but like cancellation fee clauses, the KRLTA does not expressly provide for them. ${ }^{157}$ In 2006, a bill introduced to the Kansas legislature sought to prohibit a landlord's ability to include automatic

152. $I d$

153. See Sophia Maines, Automatic Lease Renewal Can Be Costly, LAWRENCE JOURNALWORLD (Kan.), June 16, 2006, at A1 ("Automatic renewals are either a blessing or a curse, depending on what side of the fence people are on.").

154. See id. (giving an example of a situation where a tenant had until a specific date to give notice before vacating).

155. See id. (noting that those opposed to automatic renewals wanted a law prohibiting such renewals more than ninety days before the lease expired)

156. See $i d$. (reporting a resident must pay $\$ 1600$ to break a lease that was automatically renewed when she failed to give notice of her intent to vacate).

157. See id. ("The law currently makes no direct mention of automatic renewals.") 
renewal clauses in residential leases. ${ }^{158}$ Another alternative that was lobbied to the legislature in 2006 was to require the landlord to issue a written notice to the tenant as a reminder of his responsibility to notify the landlord of his intent to vacate the rental property before the automatic lease renewal took effect. ${ }^{139}$ A version of the bill passed the Kansas Senate, but failed in a House committee. ${ }^{160}$ Since the KRLTA remains silent on the enforceability of automatic renewal clauses, they continue to be included in residential leases, but the question of their legality remains unanswered ${ }^{161}$

The nature of the automatic renewal clause appears to heavily favor landlords. It triggers renewal of a lease when a tenant fails to notify the landlord of his intent to vacate the rental property in the manner prescribed in the lease, thus imposing a harsh consequence on the tenant for what is probably, at most, an unintentional or negligent failure to act. ${ }^{162}$ Another obvious benefit to the landlord is that it keeps the tenant on the hook for another lease period, thereby eliminating the hassle and expense of finding a new tenant. ${ }^{163}$ The benefit to a tenant is that he, too, does not have to deal with further lease negotiations with his landlord and is guaranteed continued living arrangements without the inconvenience or cost of searching for alternative housing. ${ }^{164}$ The downside, of course, is that the tenant who does not comply with the provisions of the automatic lease renewal clause may be unwittingly committing himself to a continued, albeit unintended, relationship with the landlord.

\section{B. Changes to the Eviction Statute}

In 2000, the Forcible Eviction and Detainer (FED) statute, formerly located at sections 61-2301 to 61-2311 of the Kansas Statutes, was repealed, recodified at sections 61-3801 through 61-3808, and renamed

158. S.B. 380, 2006 Leg., Reg. Sess. (Kan. 2006).

159. Id. Kansas House Bill 2394 proposes this as well. H.B. 2394, 2007 Leg. Reg. Sess. (Kan. 2007).

160. Maines, supra note 153.

161. Id. The Lawrence Journal-World article highlights a similar problem in Urbana, Illinois. The City of Urbana banned enforcement of automatic lease renewals within its city limits. Id. In the current Kansas legislative session, efforts to address the automatic-renewal clause have been introduced again in House Bill 2394, though no formal action on the bill has yet been taken. See supra note 159 and accompanying text (discussing House Bill 2394).

162. See Maines, supra note 153 (discussing problems tenants face with automatic renewals).

163. See id. (discussing the advantages of automatic renewals from the landlord's perspective).

164. Id. 
the "Eviction" statute. ${ }^{165}$ The substance and procedure of the summary proceeding was not altered much during the 2000 overhaul; however, in 2000 and beyond, the legislature has made amendments which are worthy of discussion. ${ }^{166}$

First, under the repealed FED statute, the landlord was required to include a claim for rent whenever an FED action was filed based on the tenant's failure to pay rent. ${ }^{167}$ This is no longer the case under the Eviction statute. Now, "if there is rent due for possession of the premises, the petition may include a request for judgment for that amount or the plaintiff may bring a subsequent lawsuit for that amount."168 This change to the summary proceeding in state court is important because, as will be discussed below, there are serious federal law implications on evictions when the landlord includes a claim for back rent. In order to avoid such implications in an eviction action, a landlord may forego collection of back rent (at least initially) and, instead, seek only immediate possession of the rental property.

The second major change, made in 2000 , concerns the demand notices that the landlord was required to provide the tenant before filing an eviction action in nonpayment of rent situations. Unlike the FED statute, ${ }^{169}$ the 2000 version of section 61-3803 did not explicitly allow the landlord to combine the three-day demand notice under the Eviction statute with the three-day demand notice under the KRLTA. ${ }^{170}$ Due to the omission of explicit language allowing for a combined three-day notice under the Eviction statute, several decisions in the Douglas County, Kansas, district court, in particular, required that the landlord issue two separate three-day demand notices-one under the KRLTA, demanding that the tenant pay rent within three days, and one under the Eviction statute, demanding that the tenant vacate the leased premises within three days. ${ }^{171}$ In 2002 , the legislature clarified that the three-day

165. S.B. 504, 2000 Leg., Reg. Sess. (Kan. 2000).

166. For a comprehensive overview of the mechanics of the FED action, see Kirschbaum, supra note 3.

167. Act of Apr. 23, 1969, ch. 290, $\S 61-2305,1969$ Kan. Sess. Laws 740, 762 (repealed 2000).

168. KAN. STAT. ANN. $\S 61-3804$ (2005).

169. See infra note 172 (discussing the new FED's notice allowances).

170. Act of May 16, 2000, ch. 161, $\$ 80,2000$ Kan. Sess. Laws 1386, 1421-22 (amended 2002).

171. Paul T. Davis, 2002 Legislative Wrap-Up, J. KAN. B. Ass'N, Aug. 2002, at 15, 21 ("[The bill amending section 61-3803] arose out of several Douglas County decisions that were requiring two separate notices to be issued in eviction cases."). In Gunter v. Eiznhamer, 196 P.2d 177 (Kan. 1948), the Kansas Supreme Court interpreted the notice-to-quit requirement under the FED statute, stating "three clear days must elapse between the date of serving the notice and the date the action is commenced." Id. at 177 (emphasis omitted). 
demand notices under both statutes may be combined, explicitly stating so in the Eviction statute. ${ }^{172}$

Lastly, in 2000 , the legislature made a relevant change to the small claims procedure. The amendment limited a person to filing no more than ten small claims in the same court during any calendar year. Importantly, this limited the number of actions a landlord could file pro se to collect back rent or actual damages from a tenant after the tenancy ended. In 2006, the legislature amended the statute yet again increasing the number of filings to twenty per year. ${ }^{173}$

\section{THE IMPACT OF FEDERAL LAW ON EVICTIONS}

\section{A. Fair Debt Collection Practices Act: $:^{174}$ General Principles Relating to Residential Evictions}

In 1977, the federal Fair Debt Collection Practices Act (FDCPA) was enacted with the purpose of protecting consumers from deceptive, abusive, and unfair collection practices of many third-party debt collectors. ${ }^{175}$ In essence, the Act requires a debt collector to refrain from engaging in threatening, rude, or obnoxious conduct in efforts to collect a debt on behalf of a creditor. ${ }^{176}$ It also requires the debt collector to provide the debtor with a written verification notice that contains the following information: (1) the debt amount; (2) the creditor's name; (3) a statement informing the debtor that there is a thirty-day period in which to dispute the debt, otherwise the debt collector will assume that the debt is valid; (4) a statement that the debtor has a right to verify the debt and

172. See KAN. STAT. ANN. $\S 61-3803$ (2005) ("The notice [of eviction] may be combined with any notice provided for in [the KRLTA].").

173. KAN. STAT. ANN. $\$ 61-2704 a$ (b) (Supp. 2006).

174. This brief discussion of the Fair Debt Collection Practices Act as it relates to state landlordtenant and eviction laws only highlights some relevant provisions of the Act and is in no way a comprehensive overview. It is strongly recommended that the reader review the full text of the FDCPA, which can be found at 15 U.S.C. $\$ \S 1692$ to $1692 p$.

175. 15 U.S.C. $\$ 1692(a)$ (2000). For further discussion of the FDCPA, see generally Laura $\mathbf{L}$. Ice, The Fair Debt Collection Practices Act: Attorneys Beware, J. KAN. B. ASs'N, Dec. 1995, at 32; Bennett S. Silverberg, Advantage Tenant: Fair Debt Collection Practices Act Gives Tenants Oversized Rackets in the Eviction Match, 8 J.L. \& PoL'Y 227 (1999); Eric M. Steven, From Landlord/Tenant to Debt Collector/Consumer and Back Again: Landlord/Tenant Notice Practice and FDCPA Compliance After Romea, 35 GoNZ. L. REV. 175 (1999/2000); Joshua P. Foster, Note, The Application of the Fair Debt Collection Practices Act to Article 7 of the New York RPAPL, 74 ST. JoHN's L. REV. 451 (2000); Kara B. Schissler, Note, Come and Knock on Our Door: The Fair Debt Collection Practices Act's Intrusion into New York's Summary Proceedings Law, 22 CARDOZO L. REV. 315 (2000).

176. See 15 U.S.C. $\S 1692$ (e) (discussing the purpose of the FDCPA as "eliminat[ing] abusive debt collection practices by debt collectors"). 
the debt collector will supply proof of the debt, if the debtor makes such a request in writing; and (5) the name and address of the original creditor in instances where the current creditor is not the original creditor, if the debtor requests the information in writing. ${ }^{177}$ The Act also requires that the debt collector include what is called a "mini-Miranda" warning in all oral and written communications with the debtor. ${ }^{178}$ This mandatory disclosure provides, in relevant part, that the debt collector is "attempting to collect a debt and that any information obtained will be used for that purpose."179

Though initially attorneys were exempt from the FDCPA, Congress later repealed this exemption. ${ }^{180}$ Confusion about the type of work (i.e., prelitigation collection efforts versus participation in pure litigation) and conduct by lawyers that would implicate liability under the Act led to the 1995 U.S. Supreme Court case of Heintz v. Jenkins. ${ }^{181}$ In Heintz, the Supreme Court held that the FDCPA applied to lawyers "regularly engaged" in the collection of consumer debt, even if those collection efforts relate to litigation. ${ }^{182}$ Although Heintz clarified that attorneys could be subject to the Act for representing clients in litigation matters, there is still debate about what it means for a lawyer to be "regularly engaged" in consumer debt collection. ${ }^{183}$

The FDCPA obviously applies to attorneys who qualify as debt collectors in efforts to secure payment of, for example, overdue medical bills or dishonored checks on behalf of creditors. ${ }^{184}$ Indeed, whether the Heinz rule applies to attorneys representing landlords in summary proceedings, such as eviction actions, seems remote, even in instances where the attorney, as a prerequisite to filing an eviction action for

177. 15 U.S.C. $\$ 1692 \mathrm{~g}(\mathrm{a})(2000)$.

178. 15 U.S.C. $\$ 1692$ (11) (2000). See also Ice, supra note 175, at 34 (referring to the Act's requirement as a "mini-Miranda" warning).

179. Id.

180. Fair Debt Collection Practices Act of 1986, Pub. L. No. 99-361, 100 Stat. 768 (1986).

181. 514 U.S. 291 (1995).

182. Id.

183. See Silva v. Mid Atl. Mgmt. Corp., 277 F. Supp. 2d 460, 466 (E.D. Pa. 2003) (holding a law firm qualified as a "debt collector" under the FDCPA because the firm accepted at least ten collection cases annually, even though the debt collection activity of the law firm amounted to only one percent of the volume of the firm's cases).

184. See Goins v. JBC \& Assocs., P.C., 352 F. Supp. 2d 262, 298 (D. Conn. 2005) (holding the owner of a law firm was a "debt collector" because the owner collected outstanding debts on behalf of his clients); see also Crossley v. Lieberman, 868 F.2d 566, 569 (3d Cir. 1989) (noting an attorney was a debt collector based on a collection letter he sent to debtor). For further discussion of "debt collectors" under the FDCPA, see Oldroyd v. Associates Consumer Discount Co., 863 F. Supp. 237, $241-42$ (E.D. Pa. 1994), where the court held that a mortgage company was not a debt collector under the FDCPA. 
nonpayment of rent, seeks to collect back rent by providing the tenant with the statutory demand notice required by state law. ${ }^{185}$ Moreover, in Kansas, it was generally the practice of attorneys representing landlords in an eviction proceeding to rely exclusively on the language of the residential lease and the laws of the state, namely the KRLTA and the Eviction statute-as long as federal housing laws or tenant subsidies were not involved. ${ }^{186}$ However, in 1998, a federal court decision arising out of a residential eviction case from the state of New York shocked many state practitioners in Kansas and across the country, quickly dispelling long held beliefs that an attorney's attempt to collect back rent for the landlord, as part and parcel of an eviction proceeding, was solely governed by state law. ${ }^{187}$

In Romea v. Heiberger \& Associates, a landlord in the state of New York sought to evict a tenant for nonpayment of rent. ${ }^{188}$ Ironically, the tenant, Jennifer Romea, did not dispute that she owed four months of rent, totaling $\$ 2800{ }^{189}$ The landlord sought the legal expertise of a law firm for assistance in collecting the past due rent from Romea and with representation in an eviction action, if it became necessary. The law firm made an attempt, in the form of a three-day demand notice as required by New York state law, to collect the rent from Romea before filing the eviction suit. ${ }^{190}$ The three-day demand notice provided, in relevant part, for the tenant to pay "the sum of $\$ 2,800.00$ for rent of the premises." It also stated, "[y]ou are required to pay within three days from the day of service of this notice, or give up possession of the premises to the landlord." 192

Thereafter, Romea filed a class action lawsuit in federal court alleging that the landlord's attorneys failed to comply with notice requirements under the FDCPA. ${ }^{193}$ Specifically, Romea claimed that the law firm's preparation and service of the three-day demand notice

185. See generally Kirschbaum, supra note 3, at 23-25 (discussing in depth the state law notice requirement for evictions).

186. See Stephen Kirschbaum, Litigating When Federal Programs are Involved, J. KAN. B. Ass'N, Sept 1996, at 32, 32-33 (discussing the implications of federal law and subsidies in state eviction proceedings).

187. See Romea v. Heiberger \& Assocs., 163 F.3d 111, 117 (2d Cir. 1998) ("Congress intended to apply the exemption only to 'process servers,' and not to those who prepared the communication that was served on the consumer.").

188. Id. at 113 .

189. Id.

190. Id.

191. Id.

192. Id.

193. Id. 
violated section $1692 \mathrm{~g}$ of the Act by failing to advise her that she had thirty days to dispute the validity of the debt. ${ }^{194}$ The law firm's failure to comply with the FDCPA, Romea argued, meant the firm was liable for civil damages under the statute. ${ }^{195}$

One of the pivotal issues in Romea was whether "back rent" was considered a "debt" for purposes of the FDCPA. ${ }^{196}$ Looking at the Act's definition of "debt," the Second Circuit determined that "back rent" fell within the definition. 197 "Debt" is defined under the Act as "an obligation ... to pay money arising out of a transaction" that involves "personal, family, or household purposes." 198 The court in Romea also made another critical determination. It held that the three-day demand notice, which the law firm drafted and delivered to the tenant pursuant to New York state law, was a "communication" under the Act. 199 The FDCPA's broad definition of "communication" is the "conveying of information regarding a debt directly or indirectly to any person through any medium."200 The effect of this determination is that the three-day demand notice required under New York state law must yield to the thirty-day notice provisions of the FDCPA if an attorney who is a debt collector subject to the mandates of the Act issues the notice to the tenant. $^{201}$

As a general proposition, the Romea decision may implicate an attorney or law firm liability under the FDCPA for participation in collecting back rent for a landlord or for representing a landlord in a summary proceeding such as an eviction action filed in state court where back rent is sought. How does Romea impact attorneys in Kansas who represent landlords in collecting back rent in eviction actions where nonpayment of rent is the basis for the suit? And does it matter if the attorney does not engage in prelitigation efforts to collect back rent for the landlord, but instead limits his participation to only representing the landlord in the eviction action where back rent is sought?

\footnotetext{
194. Id.

195. Id. Since the law suit was filed as a class action, this meant the attomey or law firm could be potentially liable for civil penalties under the statute that include actual damages suffered by each tenant, attorney's fees, and an amount up to the lesser of $\$ 500,000$ or one percent of the net worth of the attorney or law firm. 15 U.S.C. $\S 1692 \mathrm{k}$ (a) (2000).

196. Romea, 163 F.3d at 114.

197. Id. at $115-16$.

198. Id. at 115 (internal quotations omitted).

199. Id. at 116 .

200. 15 U.S.C. $\$ 1692 \mathrm{a}(2)(2000)$.

201. Romea, 163 F.3d at 116.
} 
First, it is important to note that Romea was a Second Circuit decision and is not binding in Kansas. Also, to date, the Tenth Circuit has not followed the Romea holding, ${ }^{202}$ and some jurisdictions have either criticized it, distinguished it, or expressly rejected it. ${ }^{203}$ Second, Romea only addressed the law firm's noncompliance under the FDCPA with regard to its prelitigation efforts to collect back rent from the tenant on behalf of the landlord. Romea did not address whether the attorney (or law firm) who qualifies as a debt collector must comply with the FDCPA if merely representing a landlord in an eviction action where the landlord also seeks back rent. While Romea seems to be a lone standing opinion or an aberration, attorneys representing landlords in collecting back rent or in eviction actions where nonpayment of rent is the basis for the suit should take precautions so as to avoid civil penalties for noncompliance with the FDCPA. The civil penalties under the FDCPA include actual damages suffered by the tenant, statutory damages of up to $\$ 1000$, and attorney's fees. ${ }^{204}$ If a class action is filed, as was the case in Romea, civil penalties include actual damages suffered by each tenant, attorney's fees, and an amount up to the lesser of $\$ 500,000$ or one percent of the net worth of the debt collector. ${ }^{205}$

Kansas attorneys should also be wary of Romea considering the similarities between New York and Kansas landlord-tenant law. Like New York, Kansas requires the service of a three-day demand notice upon a tenant as a prerequisite to filing an eviction action for nonpayment of rent. Specifically, section 61-3803 of the Eviction statute provides, "[b]efore a lawsuit to evict a person . . . is filed, the party desiring to file such a lawsuit shall deliver to the other party a notice to leave the premises for which possession is sought." ${ }^{, 206}$ The notice shall be delivered at least three days before commencing the lawsuit and this notice can be combined with the three-day notice under the KRLTA. ${ }^{207}$

202. The only Tenth Circuit case on point is out of the District of Colorado, where the court held an attorney representing a landlord in an eviction matter was not a "debt collector," and therefore not subject to the FDCPA, because the attorney did not regularly collect debts. Cook v. Hamrick, 278 F. Supp. 2d 1202, 1204-05 (D. Colo. 2003).

203. See Cook, 278 F. Supp. 2d at 1202 (addressing whether an attorney representing a landlord is a debt collector and therefore subject to the FDCPA); Krevsky v. Equifax Check Servs., Inc., 85 F. Supp. 2d 479, 481-82 (M.D. Pa. 2000) (holding that checks are not debt under the FDCPA); Citibank (South Dakota) N.A. v. Jones, 706 N.Y.S.2d 301, 302-03 (N.Y. Dist. Ct. 2000) (holding FDCPA does not preempt "New York common law"); Missionary Sisters of Sacred Heart, Inc. v. Dowling, 703 N.Y.S.2d 362, 369 (N.Y. Civ. Ct. 2000) (holding FDCPA did not preempt state statute).

204. 15 U.S.C. $§ 1640$ (a) (2000).

205. Id.

206. KAN. STAT. ANN. § 61-3803 (2005).

207. Id. 
The three-day demand notice under the KRLTA states that the "landlord may terminate the rental agreement if rent is unpaid when due and the tenant fails to pay rent within three days, after written notice by the landlord of nonpayment and such landlord's intention to terminate the rental agreement if the rent is not paid within such three-day period."208

In practice, if the tenant does not pay rent when it is due, the landlord (or its attorney) can provide the tenant with a combined three-day notice under the KRLTA and the Eviction statute, giving the tenant two options: pay rent in full or vacate the leased premises within three days. ${ }^{209}$ The combined three-day demand notice must further state that the tenant's failure to pay rent or vacate the rental property may result in legal proceedings. In Kansas, a landlord's failure to provide this combined three-day notice to the tenant prior to filing the eviction action means that the court lacks jurisdiction to proceed with the merits of the eviction, thus resulting in dismissal of the case. ${ }^{210}$

\section{B. Strategies for Maintaining FDCPA Compliance}

In light of Romea and the similarities between Kansas and New York landlord-tenant and eviction law, it is possible a Kansas attorney may have to defend against a tenant's claim of a FDCPA violation. The strategies and considerations contained in the following subparts may help the landlord and its attorney determine whether compliance with the FDCPA is necessary and if so, how compliance can be achieved.

\section{The Landlord Need Not Comply Because He Is Not a "Debt Collector" Under the FDCPA}

If the landlord seeks back rent from the tenant, the landlord himself could deliver the combined three-day demand notice under the KRLTA and the Eviction statute without complying with the FDCPA because a creditor seeking to collect its own debt is not subject to the Act. ${ }^{211}$

Should the tenant fail to pay rent or vacate the rental property as requested in the three-day demand notice, then the attorney may file the

208. KAN. STAT. ANN. § 58-2564(b) (2005).

209. Typically, most leases have a grace period ranging from three to five days in which a tenant may pay the rent before the landlord issues the three-day demand notice, but the tenant is usually assessed a late fee during this grace period.

210. Goodin v. King, 387 P.2d 206, 210 (Kan. 1963); Bell v. Dennis, 144 P.2d 938, 940 (Kan 1944).

211. See 15 U.S.C. $\$ 1692 \mathrm{a}(6)$ (2000) (stating that, to be a debt collector under the FDCPA, one must be collecting debts "due another"). 
eviction petition on behalf of the landlord, alleging nonpayment of rent as the basis for the suit. Whether the attorney must comply with the FDCPA when merely filing the eviction action in which back rent is also sought may depend on, at least, two important considerations: (1) whether the attorney is a debt collector under the Act; and (2) whether the Act requires compliance for only filing the eviction action on behalf of the landlord. Romea does not speak to the issue of whether an attorney who is a debt collector must comply with the Act when filing an eviction action seeking back rent, though Heintz hints that compliance with the FDCPA in litigation matters is necessary if the attorney is a debt collector attempting to collect a debt on behalf of a creditor even if the collection of back rent is part and parcel of the eviction action.

\section{The Attorney Who Is Not a "Debt Collector" Under the FDCPA Need Not Comply}

If the attorney is not a debt collector under the Act (or under Heintz), then the attorney is not required to comply with the Act. This means that in instances where the landlord seeks back rent from the tenant, the attorney can prepare and deliver to the tenant the combined three-day demand notice under Kansas law on behalf of the landlord without the possibility of facing civil penalties under the FDCPA. It also means that the attorney can file the eviction action and seek back rent from the tenant without violating the Act.

As mentioned previously, the question about whether an attorney qualifies as a debt collector is an ongoing debate. Though it may be arguable that a specific attorney does not "regularly engage" in debt collection so as to make him subject to the Act, it is possible that the tenant could likely assert that the attorney is a debt collector under the Act. In such case, the attorney must meet and defeat this challenge. As a safeguard, an attorney who seeks to collect any debt on behalf of a creditor should comply with the FDCPA, even in the eviction context, where the attorney's representation in collecting back rent is secondary to seeking lawful possession of the rental property on behalf of the landlord.

\section{Actions Constituting an Attorney's Full Compliance with the FDCPA}

Whether the landlord's attorney must comply with the FDCPA when merely filing the eviction action on behalf of the landlord who is also seeking back rent remains unclear because Romea hinged on the law 
firm's prelitigation efforts to collect back rent from the tenant. It seems plausible that if the landlord seeks to collect its own debt by delivering a three-day demand notice to the tenant and is unsuccessful, then nonpayment of rent becomes the legal basis for the eviction action, and the attorney should not be held liable under the Act for failing to comply with its notice requirements. However, the eviction petition seeking back rent from the tenant may be considered a "communication" under the FDCPA's broad definition of the term; therefore, if the attorney is a debt collector, he must comply with the notice requirements of the Act or face civil penalties. Consequently, because the civil penalties for violating the FDCPA are harsh and may be unavoidable, any attorney is well-advised to comply with the FDCPA if he is representing a landlord in an eviction matter seeking back rent.

Full compliance with the FDCPA creates at least two distinct options for attorneys to follow when handling eviction actions where nonpayment of rent is the basis for the suit. The practical effect of either is that compliance with the FDCPA gives the tenant more time to remain in the rental property without paying rent. That is, the landlord must wait longer to gain lawful possession of his rental property without receiving the tenant's monthly rent.

Under the first option, if the landlord issues the combined three-day demand notice under Kansas law and the tenant does not comply with terms of the notice, the attorney can file an eviction lawsuit seeking back rent. $^{212}$ In the eviction petition, the attorney should include all of the information required in the FDCPA verification notice. Then, the attorney should allow thirty days for the tenant to answer the petition or for the tenant's first appearance in the eviction action to be scheduled. ${ }^{213}$ The petition should also include the mini-Miranda disclosure. Once thirty days have lapsed or all requirements of the FDCPA have been fulfilled, the eviction action can proceed as provided in the Eviction statute.

The second option considers the attorney's involvement as a debt collector in issuing the combined three-day demand notice required under state law. If the landlord enlists the attorney to issue the combined three-day demand notice, the attorney should allow the tenant thirty, rather than three, days to comply, thereby yielding to the notice

212. See supra notes $207-11$ and accompanying text (discussing three-day demand notices).

213. Under section 61-3805 of the Kansas Statutes, once the eviction petition is filed, the court shall determine when the first appearance shall be scheduled. The statute states that "[s]uch time shall be not less than three nor more than $\mathbf{1 4}$ days after the date the summons is issued." KAN. STAT. ANN. § 61-3805 (2005). 
requirements of the FDCPA. ${ }^{214}$ This means that the tenant will be given a minimum of thirty days to pay rent or vacate the rental property before the attorney files the eviction action seeking back rent. Once the eviction petition is filed, the process for the summary proceeding follows the timeline provided for in the Eviction statute.

\section{Attorneys May Expedite the Eviction Action, but Not Seek Back Rent, Without Full Compliance}

Finally, the last consideration involves a scenario where the landlord foregoes collection of back rent in the summary proceeding in order to expedite the eviction process. Compliance with the FDCPA is a potential issue only when a debt collector is seeking back rent from the tenant on behalf of the landlord. Thus, to safely avoid implication of the FDCPA altogether, when nonpayment of rent is the basis for the tenant's breach of the landlord-tenant agreement, the landlord himself should issue the combined three-day demand notice to the tenant. If the tenant fails to comply with the demand notice, the attorney can then file the eviction action using nonpayment of rent as the basis for the suit but not include the landlord's request for back rent. Then, payment of back rent will not necessarily be an issue for the court to consider in the eviction proceeding, ${ }^{215}$ and compliance with the FDCPA is not required. Omission of a request for back rent in the eviction action permits the attorney to bypass the FDCPA and allows the landlord to gain immediate possession of the rental property under the state's eviction proceeding. If the landlord employs such a strategy, he may file an action to collect rent later using other legal avenues such as small claims court. ${ }^{216}$

214. The FDCPA states, in relevant part, a "debt collector shall ... send the consumer . . . a statement that unless the consumer, within thirty days after receipt of the notice, disputes the validity of the debt . . the debt will be assumed to be valid." 15 U.S.C. $\$ 1692 \mathrm{~g}(\mathrm{a})(3)$ (2000).

215. See KAN. STAT. ANN. $\$ 61-3804$ (2005) ("If there is rent due for possession of the premises, the petition [for eviction] may include a request for judgment for that amount or the plaintiff may bring a subsequent lawsuit for that amount.").

216. The landlord's filing of an eviction action "shall not be a bar to any subsequent lawsuit brought by either party for claims not included in such judgment." KAN. STAT. ANN. \$ 61-3802 (2005). Similarly, section 61-3804 leaves it to the discretion of the landlord to request back rent in the eviction action. It provides: "the petition may include a request for judgment for that amount [of back rent] or the plaintiff may bring a subsequent lawsuit for that amount." KAN. STAT. ANN. § 613804 . 


\section{The Impact of the Bankruptcy Code ${ }^{217}$ on Evictions}

Another area of federal law that could potentially impact residential evictions is the Bankruptcy Code's automatic stay found at 11 U.S.C. $\S$ 362(a). ${ }^{218}$ The relevant provision, section 362(a)(3), states that, upon the filing of a bankruptcy petition, an automatic stay becomes immediately effective against "any act to obtain possession of property of the estate or of property from the estate or to exercise control over property of the estate." 219 Simply put, a residential tenant who files for bankruptcy and who is being evicted by the landlord from his rental home is protected by the automatic stay under federal law, thus immediately halting the state eviction action. ${ }^{220}$ In many cases, the unfortunate result for the landlord seeking to evict the tenant is that the tenant is not paying rent, but is allowed to remain in the rental property until the landlord pursues proper remedies in bankruptcy court. ${ }^{221}$

Oftentimes, the landlord's hassle of dealing with the automatic stay in the eviction context arises in an unsuspecting way. The following scenario illustrates how the automatic stay can affect the state eviction action and thereby prevent the landlord from gaining lawful possession of his rental property. This all to common scenario involves a tenant who has not paid monthly rent or vacated the leased premises despite the landlord's issuance of the combined three-day notice under Kansas law. After proper statutory notices have been issued to the tenant under state law, ${ }^{222}$ the landlord files an eviction action in state court seeking possession of the rental property and back rent from the tenant. The tenant is served with the petition for eviction and, soon thereafter, the landlord is notified either in the tenant's answer or during the tenant's first appearance in the eviction action that the tenant has filed for bankruptcy. The revelation that the tenant is in the midst of a bankruptcy

217. The Bankruptcy Abuse Prevention and Consumer Protection Act of 2005 (BAPCPA) amends various provisions of the 1978 Bankruptcy Code (also amended in 1994). This brief discussion of BAPCPA as it relates to state eviction laws highlights some key provisions of the Bankruptcy Code and is in no way a comprehensive overview. It is strongly recommended that the reader review the full text of the Bankruptcy Code and the BAPCPA amendments, which can be found at 11 U.S.C. $\$ \S 101$ to 1532 (Supp. 2006).

218. 11 U.S.C. $\$ 362$ (a) (Supp. 2006). The Bankruptcy Code was enacted in 1978, amended in 1994, and amended again in 2005. Richard C. Maxwell \& B.Webb King, Bankruptcy Law, 40 U. RICH. L. REV. 53, 53 (2005).

219. 11 U.S.C. $\$ 362(a)(3)$.

220. Alan M. Ahart, The Inefficacy of the New Eviction Exceptions to the Automatic Stay, 80 AM. BANKR. L.J. 125, $126(2006)$.

221. Id.

222. The landlord has presumably also complied with the notice requirements of the FDCPA if it applies. 
may be daunting for the landlord and raises many questions about how the landlord may proceed, if at all, with the eviction process.

Once the landlord is notified or becomes aware that the tenant has filed for bankruptcy, it is important for the landlord's attorney to determine how the tenant's bankruptcy will affect the state eviction proceedings. ${ }^{223}$ Likely, a state court judge will stay the eviction action until he receives clarification from the bankruptcy court or trustee about whether the state court has jurisdiction to proceed with the eviction action. In any event, because the issue of federal law has presented itself in the state eviction action, if the landlord wishes to continue with the eviction process, he must seek the expertise of a lawyer to advise and assist him in clarifying the status of the tenant's bankruptcy. More frustratingly for the landlord is that he may also have to wait additional time to gain lawful possession of his rental property.

In 2005, new amendments to the Bankruptcy Code known as the Bankruptcy Abuse Prevention and Consumer Protection Act (BAPCPA) sought to address the prolific and systematic abuse and injustice of the automatic stay which occurs in the residential eviction context as described in the foregoing example. ${ }^{224}$ Specifically, two narrow eviction exceptions to the automatic stay were enacted in 2005 , but because the creation of the two exceptions is fairly recent, it is difficult to assess whether they provide landlords the relief Congress intended.

The first eviction exception, called the prepetition judgment exception, allows a residential landlord, under certain circumstances, to proceed with executing a judgment of possession against the tenant if the state judgment was obtained before the tenant filed for bankruptcy. ${ }^{225}$ This exception to the automatic stay does not appear to be "automatic" in the true sense. Rather, the exception includes tedious procedural steps that must be taken in bankruptcy court before the landlord can safely

223. If the attorney representing the landlord in the state eviction case is unfamiliar with the implications of the automatic stay, the attorney should seek counsel or assistance from an attomey who is familiar with the Bankruptcy Code.

224. For further discussions of such problems, see generally John C. Anderson, Highlights of the Bankruptcy Abuse Prevention and Consumer Protection Act of 2005-Part I-Consumer Cases, 33 S.U. L. REV. 1, 18-19 (2005); Christopher A. Camardello, Landlords, Tenants, and the New Bankruptcy Amendments, BENCH \& B. MINN., Oct. 2005, at 20; Henry E. Hildebrand, III \& Keith M. Lundin, Selected Changes Affecting Consumer Bankruptcy Practice in the Bankruptcy Abuse Prevention and Consumer Protection Act of 2005, 59 CONSUMER FIN. L.Q. REP. 370, 373-79 (2005); Richardo I. Kilpatrick, Selected Creditor Issues Under the Bankruptcy Abuse Prevention and Consumer Protection Act of 2005, 79 AM. BANKR. L.J. 817, 821 (2005); Leases: New Law Aids Landlords, REAL EST. L. REP., Aug. 2005, at 5; Patrick E. Mears \& John T. Gregg, What Congress Hath Wrought, PROB. \& PROP., Nov.-Dec. 2005, at 24-26.

225. 11 U.S.C. $\S 362$ (b)(22) (Supp. 2006). 
proceed with executing the judgment and writ for possession. Accordingly, the landlord's relief from the automatic stay under this exception is not clear cut and may not be immediate, so it is critical for the landlord to receive proper counsel from an attorney who is wellversed in bankruptcy law and its new eviction exceptions to the automatic stay before executing a state judgment for possession.

The second eviction exception to the automatic stay provides that the landlord can proceed with an eviction action if the basis for the suit is the tenant's illegal use of controlled substances or endangerment of property. ${ }^{226}$ Like the first eviction exception, there are certain mechanics to this exception that must be considered but, on the whole, complying with this exception appears less cumbersome than the prepetition judgment exception. Again, the landlord should receive expert advice on how to employ this exception, if indeed there is a basis for the landlord to invoke it.

Though BAPCPA's two exceptions to the automatic stay were enacted to alleviate the unfairness and injustices that many landlords face as a result of a tenant's bankruptcy, one must wonder whether the exceptions have fully resolved the possible financial hardship that a landlord faces when a tenant fails to pay rent. In addition, it is debatable whether the unavoidable inconvenience and expense of having to hire competent legal counsel to address the technical procedures in bankruptcy and state courts allow these burdens to truly be alleviated.

\section{CONCLUSION}

Anymore, the landlord-tenant relationship should be viewed with trepidation from the landlord's perspective. In the state arena, the landlord generally must adhere to strict compliance with the KRLTA and the Eviction statute in handling all matters concerning tenants. Otherwise, the landlord may be limited in the remedies he may seek against the tenant in state court. As well, in some instances, such as wrongful withholding of a tenant's security deposit, the court may in fact sanction the landlord for noncompliance with the KRLTA. Complicating matters further for the landlord is the mixture of federal and state law, which poses additional challenges for the landlord and his attorney to consider. In the eviction context especially, where nonpayment of rent is the basis for the eviction action, the attorney representing the landlord should be well-versed in Kansas law and the relevant federal statutes, 
such as the FDCPA and the newly amended Bankruptcy Code, so as to provide competent legal representation to the landlord.

Similarly, there may be instances where the tenant should be wary of the landlord-tenant relationship. For example, a landlord's inclusion of a cancellation fee clause within the lease may produce unfair results for a tenant who prematurely terminates a residential lease. Also, an automatic lease renewal provision included within a lease may have unintended consequences for a tenant who fails to comply with its terms. Like all parties who enter into contracts, both the landlord and the tenant should approach their lease agreement with full understanding of the terms and the law to which they are bound. 